\title{
Selected Chapters of Greece's Law of Obligations under the Limelight of European Law
}

\author{
PhD (Uni Graz) Dr. Mag. lur (Uni Graz) Endri Papajorgji
}

Karl Franzens Universität Graz, Universiteti Luarasi endripapajorgji@hotmail.com

\author{
Doi:10.5901/mjss.2014.v5n20p127
}

\begin{abstract}
Greece is member of the EU since 1.1.1981. The accession of Greece to the European Community was signed and ratified by the Greek Parliament in 1979 with a majority of 193 votes out of 300. Article 28 of the Constitution of 1975 provided the legal basis of the incorporation of Community law into the Greek legal order. According to article 28 competencies provided by the constitution can be vested in agencies of international organizations by treaties or agreements, when this serves an important national interest and promotes co-operation with other states. European Community law has pervasive effects upon the Greek legal order and the regulations have direct applicability and effect in Greece. When required, domestic law is adapted to the provisions of Community law. In addition, Greek law belongs to the civil law tradition. The era of modern Greek law began with the National Revolution of 1821 against the Turks, which led to the creation of the Greek State in 1830. The most important codifications in Greek law are the following: Civil Code, Commercial Code, Penal Code, Code of Civil Procedure, Code of Criminal Procedure, Code of Private Maritime Law and Military Penal Code. The Greek Civil Code of 1946 was greatly influenced by Byzantine law, which was applied in Greece before the drafting of the Civil Code. The Civil Code is founded on the principles of personal autonomy, private property and freedom of contract. It also protects the institution of family, with equality between the sexes, being constitutionally proclaimed. It contains, however, general clauses, leaving space for judicial adaptation to changing circumstances aswell as for the introduction of elements of fairness. Main objective of this paper is to analyze Greece's Obligations law in a comparative view with the European law.
\end{abstract}

Keywords: Obligations law, reform, Greece, Integration, EU.

\section{Introduction}

Basis of the current Greek private law is the Civil Code from 1940/46 (in below GCC), which builds with some other laws the Greek civil law within the meaning of general private law. The regulation of trade and business law, labor and copyright law, however, is mainly regulated through special laws. Only the rules of private international law are found largely in the Civil Code. The Civil Code is based in large parts in the German Civil Code, which is due to the fact that both legal systems are based on Roman law, whose provisions were in force in the Greek state over fourteen hundred years (Papajorgji 2012). There are also some isolated influences of the French and Swiss civil law. The GCC is characterized by its liberal-democratic stance and his social character. Its structure follows those of the German and Austrian Civil codes and consists of five-parts: the General Part follows the Law on bligations, the property law, family law and inheritance law. In addition to the Civil Code as the central rules of the Greek private law system there are also numerous individual statutory provisions, which are in the social, economic and technical developments that were incorporated into Greek law in accordance with the EU directives (Gärtner 1996). This includes especially the field of consumer and environmental protection. The Greek private law is also necessary for the enforcement of the substantive law in the specific case of public law belonging to civil procedure law (Athanasios, 1986).

The judiciary system implies that Greek courts do not possess a law-making capacity as such. Courts, therefore, are not formally bound by judicial precedent. Nevertheless, courts only seldom depart from prior established practice reflected by a series of decisions. Established practice in decisions of the higher courts and especially those of the "Areios Pagos" (the Supreme Civil and Criminal Court) play an important role in the decision-making process of the lower courts. In a similar manner, the works of legal scholars have the potential of influencing both the legislators in enacting the law and the courts in interpreting it (Papajorgji 2013).

\section{General Part of Law of Obligations}

The provisions of the law of obligations are largely regulated in the second book of the Civil Code (Articles 287-946). 
Legal liability provisions in the form of general private law can be found in addition in other books of the Civil Code and in particular provisions outside. The Articles 287-495 govern the general law of obligations, and contain - analogous to the German law - applying to all obligations general provisions. In this sense, the Articles 287-334 contain definitions for obligation (Article 287). This definition states the obligation of the Debtor, which has the power to fulfill his obligation in good faith with regard to the common usage (Article 288) and include provisions to generic, money, and interests (Article 289-296). The following notes include some important principles of contract law. Differently from the Austrian law, which regulates in Article 1323 of the ABGB (Austrian Civil Code) the principle of restitution over the monetary compensation, the fulfillment of the damages is based primarily on Article 297 by making cash payment. The restitution is in contrast the exception and is in accordance with judicial discretion only if a sufficient compensation is applied for the damages that can be achieved taking into account the interests of the creditor (Perakis 2008).

The extent of the compensation covers both the outflow of the victim (positive damage) as well as the loss of profit (Article 298). In the case of immaterial damages, a monetary compensation, however, is required only in the cases established by law (Article 299). The Articles 320-324 contain provisions on performance, time and place of performance which shall always be subject to party autonomy. If there is no agreement concerning the performance time from the circumstances and in particular the purpose and nature of the agreement does not derive, the debtor has to deliver full power immediately, and on the other hand, the creditor can demand performance immediately (Article 323). If the parties, however, agreed on a performance time, so it is up to the debtor in case of doubt, to afford a debt-discharging even before that date. Also with regard to the place of performance, the law states for the case that the latter can be either from the agreement of the parties or from the circumstances, in particular the purpose and nature of the agreement can be determined (Perakis 2008).

Basically, the performance is to be provided at that place where the debtor at the time of the liability was domiciled. If there is a requirement under the business operations of the debtor then the place of his business establishment is displayed as the place of performance (Stathopoulos 2009). Article 320 regulates the question of the place of performance in the sense of a collectable debt. The situation is different when a monetary amount has to be paid. If in doubt, the residence of the creditor or his place of business or performance has to be accepted. Monetary obligations are therefore generally debts. According to Article 330 of the GCC, the debtor is liable for any willful or negligent failure of the fulfillment of the contractual obligation. The liability also extends to the poor performance (Yessiou 2011). The resulting gap tries to fill the ruling doctrine, by the analogous application of the provisions on default and impossibility (Athanasios, 1986). As of Article 332 GCC, also void are such agreements under which the debtor would like to exclude or limit its liability for slight negligence in advance if:

- the creditors are in service of the debtor,

- the disclaimer is in a contract condition, that is not subject to individual agreement or

- the disclaimer refers on the violation of personal (Especially life, health, liberty or honor).

According to Article 334, the debtor shall be liable for the conduct of a third party, whose help he uses for the performance of its obligation, as for his own. Any exclusion or limitation of liability in advance is subject to one of the situations of the Article 332 (ie only for slight negligence if none of the cases of Article 332 para 2 is satisfied). The rules for the impossibility of performance and default of the debtor can be found in the Article 335-348, that of the creditor default in Art 349 - 360. Unlike the German law, the Civil Code does not differentiate between initial and subsequent impossibility and treats equally the objective and subjective impossibility of performance. The rules on impossibility of performance are dependent on the fault of the debtor. Specifically, this means that the provision of a service is objectively impossible; the contract is initially effective, the debtor is therefore obliged to pay damages, if the services are wholly or partly dependant from reasons that are generally attributable to the debtor (Athanasios, 1986).

Chapter 6 of the second book, contains provisions to six reasons that lead to the extinguishment of the debt. This design is similar to the Austrian law (see, for example, § 1412, § 1425, §1438, §1445 of the ABGB/Austrian Civil Code) and shall consist of the

- $\quad$ Fulfillment (Article 416-426), the

- Deposit (Article 427-435), the

- Novation (Article 436-439), the

- Compensation, (Article 440-452), the

- Association of debtor and creditor position (confusion, Article 453) and

- Remission of guilt (Article 454). 


\section{Special Part of Law of Obligations}

The Articles 496-946 contain specific provisions on the individual contractual and legal obligations, such as: the provisions on the donation (Art 496-512), purchase and exchange (Art 513-573), rent (Art 574-618), land lease (Art 61947), service contracts (648-680), broker agreements (703-708), competition (Art 709-712). The special law of obligations is in full compliance with the Consumer Sales Directive ${ }^{1}$ in the areas of defects liability and unjust enrichment. In this sense, the implementation of the Consumer Sales Directive has helped to achieve European harmonization of the purchase contract law and the creation of common minimum rules of consumer's law, valid in every state of the EU, no matter where goods are purchased in the community (Stathopoulos 2009). These changes took place in Greece with law on the liability of the seller for defects, whose provisions were included in the Civil Code. In this way the rules relating to the liability for defects changed (in particular Articles 534-537 and 540-561 of the Civil Code). In contrast to the requirements of the Consumer Sales Directive, the provisions of the Civil Code shall apply, also to contracts between private individuals and do not refer to the relationship seller/consumer. A Central criterion of the new liability for defects in the Greek Civil Code is the lack of conformity of the purchased goods. According to Articles 534 and 537, paragraph 1 of the Civil Code, the seller is committed to deliver goods free of errors and under the conditions prescribed by the contract, which defines that he is responsible for ensuring it. The seller does not fulfill his obligation if he doesn't provide the purchaser with the appropriate thing (Article 535). Part of the doctrine therefore includes not only the defective delivery, but also the classification and quantity deviations claimed under the new liability for defects, even if this is not expressly regulated in the law. The implementation of Article 8 of the Consumer Sales Directive, is regulated in Article 545, that includes four criterias, which serve at the same time the burden of proof of the buyer (it involves a purely declarative enumeration, so that the buyer can also support other criteria) (Stathopoulos 2009). The presumption of non-conformity of a thing accordingly engages when these:

- are not in fully accomplishment with the described thing that the parties entered into the agreement, or are not in accordance with the sample or model that was submitted by the buyer;

- are not in accordance with the specific purpose of the contract, in particular not suitable for matching with the special object of the contract;

- are not for those use, for which the things of the same kind are usually determined and

- do not prove those quality or performance that the buyer expects in terms of the same type.

The inclusion of advertising and labeling in the concept of non-conformity makes the assumption of a contractual agreement between seller and buyer obsolete, since the unilateral declaration of the seller sufficiently triggers its liability (Athanasios, 1986). However, the forementioned cases are only references to any concrete object of the matter. The liability of the seller engages only for initial defects, ie those who have already passed at the time the risk passes to the buyer and didn't occur later (Article 537). Same as the Austrian law (§ 924 Austrian Civil Code), the GCC contains a statutory presumption that the defect or lack of conformity existed already during the delivery of the thing, provided that it became evident within six months after the date of transfer (Article 537 para 2). In this area, the courts enjoys a significant degree of discretion, as the things or the presumption of the nature of the goods or the nature of the defect can reject the lack of conformity (Art 537 para 2). A breach of contract and thus the warranty obligation for the seller is then not given, if the buyer knew about the defect at the time of the agreement of the contract (Article 537 para 1). The remedies of the Purchaser pursuant to the liability for defects are analogous to the Austrian legislation (Papajorgji 2012). However, Article 540, paragraph 1 includes the right to terminate the contract at a merely slight breach of contract explicitly.

The GCC has devoted a separate chapter for claims of unjust enrichment (Article 904). Article 904 of GCC implies that the one, who enriches itself without a legal basis at the cost or the damage of another, is obliged to give back the advantage obtained. The law states particular cases in which the unjust enrichment is a result of the undue power or is based on a not occurred successful performance or from a later unlawful or immoral reason (Perakis 2011). The recovery of already provided services is excluded when the service provider knew about the non-existence of the debt. The burden of proof is provided by the beneficiary. In case of violation of property rights, the provisions of unjust enrichment can be used. The claim for unjust enrichment is always subsidiary, so it can only be invoked if the injured deserves no entitlement under other provisions.

The Articles 914-938 of GCC deal with tort law and are adapted to a large extent with the provisions of the German Civil Code. In some areas, however, the Greek tort law differs significantly from German law. This firstly concerns the

${ }^{1}$ Directive 1999/44/EC of the European Parliament and of the Council of 25 May 1999 on certain aspects of the sale of consumer goods and associated guarantees, L 171, $0012-0016$. 
central provision of the tort. Article 914 contains no enumeration of legal interests, but determines general clauses, for example the person who unlawfully and culpably caused damage, is required to replace the same damage. In addition, there are a number of special cases, such as the deliberate immoral damage (Article 919), credit risk (Article 920) or the the claim for damages caused indirectly by the injured party in the case of death or personal injury (Article 928).

The consumer protection is no longer a rarity even in Greek law. Such provisions are found both under the provisions of the Civil Code, but also through special laws. Under the influence of Community law has, Greece has reached a very high degree in the area of consumer protection at the national level. The core of the Greek consumer protection law is in compliance with European legal requirements (Stathopoulos 2009).

The notion of consumer is broad and defined as "natural and legal persons and associations without legal personality", "for which the products or services are available on the market or in use of such products or services, provided that they represent the final destination." Also, each recipient of advertising is a consumer within the meaning of the Greek Consumers Law (GCL). Article 2 of the GCL deals with the general terms and conditions in consumer contracts. In this sense, a clearly visible notice at the place of the contract is sufficient. Paragraph 2 provides guidance on language and wording of the terms and conditions, which can be easily understood by the consumer. The Articles 3, 4 and 5 of the GCL contain provisions to contract outside of the business place and "consumer goods and guarantees" (Stathopoulos 2009).

Article 6 of GCL states the strict liability of the manufacturer for any damage that is attributable to a defect in his product. The term of the manufacturer is regulated within the definition of paragraph 2 that includes the presentation of producers by affixing the name, mark or other distinctive mark. Also the importer is considered a manufacturer within the meaning of Article 6 (paragraph 3). In the event that the manufacturer can not be determined, Article 6 paragraph 4 provides the possibility of raising a claim of the injured to the distributor for the product. If the amount of loss is less than $€$ 500 , the injured party has to bear the damage himself. A violation of the provisions of Article 6 is connected with a monetary compensation in the event of non-pecuniary damage (para 7). The manufacturer's liability is excluded pursuant to paragraph 8, if he furnishes proof that:

a) He did not put the product into circulation;

b) He has not manufactured the product with the intention to bring it into circulation and

c) The defect is due to the fact that the product was fully produced in compliance with mandatory legal requirements;

d) The defect is due to the fact that the product was fully produced in Compliance with the updated state of science and technology.

Two or more persons are liable for the injured party jointly and severally. However, they can internally accord to the respective share of the damage (Stathopoulos 2009). Agreements, by which the liability of the manufacturer is limited or excluded in advance, are invalid. Claims for damages of the consumer against the manufacturer include a three years term from the date on which the injured party has become aware of the damage, the defect and the identity of the manufacturer. After the expiry of ten years from the date of introduction of the product in the market, all claims against the manufacturer are invalid (Perakis 2011).

The peaceful settlement of disputes between distributors and consumers or consumer organizations are regulated through extrajudicial execution of Article $11 \mathrm{GCL}$ through the establishment of special Committees, each consisting of a lawyer of the local Bar Association, a representative of the distributor and a representative of the local consumer associations, in each prefecture. Article 12 provides, finally, the establishment of the "National Consumers Council". It is a composite made up of representatives of consumers, workers and employers, as well as generally recognized personality's that have a good knowledge in the field of consumer protection. The main duties of the Council are the protection of the consumer through the policies and the strengthening of the influence of consumers.

\section{Conclusions}

The following paper gave e clear idea of the main areas of the Greek law of obligations and consumers protection. The European practice regarding the law of obligations and especially the consumer's sales directive and the consumers protection has became part of the Greek private law practice. The changes that occurred in the consumer's protection in Greece are not that substantial, as a consequence of the system of free market economy that was implied in Greece after the II World war.

The compliance of Greece's legislation with the EU has built a solid basis for the harmonization of the national private law (especially obligations law) with the EU acquis communutaire. This need has been achieved not only with the basic principles of law of obligations, but also with the special part. Fulfillment (Article 416-426), Deposit (Article 427-435), 
Novation (Article 436-439), Compensation, (Article 440-452), the Association of debtor and creditor position (confusion, Article 453) and Remission of guilt (Article 454) are only examples of this special part of law of obligations, but also gifts, sales, leases, partnerships, production contracts, employment contracts, surety, loans, etc., and also negotium gestio, restitution and torts are harmonized with the EU law.

In addition, this paper presented a comparative view of the Greek legal system with the German and Austrian legal definitions. The General Law of Obligations (genikon enohicon dikaion) consists of no exhaustive list of all the possible types of agreements that can be made. The underlying principle in the Law of Obligations is the principle of freedom of contract and the parties are free to create all kinds of obligations to fit their needs, which is also a principle in Germany and Austria.

It is also worth noting, the implementation of Directive 1999/44/EC of the European Parliament and of the Council of 25 May 1999 on certain aspects of the sale of consumer goods and associated guarantees in the Greek legislation system.

\section{References}

Athanasios, L (1986), An outline of the Greek civil law, Athens.

Gärtner, W. (1996), Die Eigentumsgarantien in den Verfassungen Polens, Ungarns, der Tschechischen und der Slowakischen Republik. Verfassungsrechtliche Grundlagen und Verfassungspraxis, Eigentum in Osteuropa. Peter Lang, Berlin, p. 219.

Papajorgji, E. (2012), E drejta ndërkombëtare tregtare dhe e biznesit. Tiranë.

Papajorgji, E. (2012), E drejta europiane private. Tiranë.

Papajorgji, E. (2013), Privatisierung von Unternehmen in Albanien und Mazedonien im Rechtsvergleich. Saarbrücken.

Perakis, K (2008), Contract law in Greece, in Tuğrul Ansay, Jürgen Basedow, Structures of Civil and Procedural Law in: South Eastern European Countries. Vienna.

Stathopoulos, K (2009), Contract law in Greece Athens.

Yessiou, $\mathrm{F}$ (2011), Civil Procedure in Greece. London.

Directive 1999/44/EC of the European Parliament and of the Council of 25 May 1999 on certain aspects of the sale of consumer goods and associated guarantees, L 171, $0012-0016$.

GCC/Greek Civil Code from 1940/46.

ABGB/Austrian Civil Code.

BGB/ German Civil Code. 